\title{
An evaluation of deuterium as a food source tracer in temperate streams of eastern Canada
}

\author{
Timothy D. Jardine ${ }^{1}$ AND Karen A. Kidd ${ }^{2}$ \\ Canadian Rivers Institute and Department of Biology, University of New Brunswick, Saint John, \\ New Brunswick, Canada, E2L 4L5 \\ Richard A. Cunjak ${ }^{3}$ \\ Canadian Rivers Institute and Department of Biology, University of New Brunswick, Fredericton, \\ New Brunswick, Canada, E3B 5A3
}

\begin{abstract}
Stable $\mathrm{H}$ isotope ratios $(\mathrm{D} / \mathrm{H}$, expressed as $\delta \mathrm{D})$ hold promise as an additional tool for elucidating food sources for consumers in aquatic ecosystems. We tested the applicability of $\delta \mathrm{D}$ as a food source tracer in streams of New Brunswick, Canada. First, we analyzed $\delta \mathrm{D}$ and $\delta^{13} \mathrm{C}$ in biofilm and terrestrial leaves and compared signal-to-noise ratios (variability within sources vs variability between sources) between the 2 elements. Signal-to-noise ratios were roughly similar, and 23 of the 31 sites had isotopically distinct food sources based on $\delta \mathrm{D}$ compared to 20 of 31 based on $\delta^{13} \mathrm{C}$. Second, we used mixing models to estimate \% aquatic $\mathrm{H}$ and $\%$ aquatic $\mathrm{C}$ for benthic invertebrates at a subset of sites. Of 16 samples, only 1 had $\delta^{13} \mathrm{C}$ that was outside the range of the 2 food sources (yielding \% aquatic $\mathrm{C}>100 \%$ ), but 12 of the 16 samples had $\delta \mathrm{D}$ outside the range of the food sources, a result suggesting confounding effects of water and lipids on total body $\mathrm{H}$ content. Last, we analyzed $\delta \mathrm{D}$ in laboratory-reared consumers (brook trout and water striders) and in their diet before and after lipid extraction to estimate diet-tissue fractionation. Large differences between consumer and diet were apparent before lipid extraction, but no significant differences were found after lipid extraction. All of these measures indicate that $\delta \mathrm{D}$ could serve as a complementary, but not alternative, isotopic method for estimating food sources for consumers in streams. Further laboratory trials are needed to explore the influence of lipids on $\delta \mathrm{D}$ values.
\end{abstract}

Key words: hydrogen, diet-tissue fractionation, signal-to-noise, mixing models, lipids, exchangeable $\mathrm{H}$, biofilm, alder.

The provision of energy to streams controls consumer productivity (Wallace et al. 1997) and a variety of functional interactions (Thompson and Townsend 2005) and is essential in maintaining biodiversity and other ecosystem attributes. A full understanding of predominant food sources at various scales in lotic ecosystems has long been a challenge (Vannote et al. 1980, Junk et al. 1989, Thorp and Delong 1994). Analysis of stable isotope ratios of $\mathrm{C}\left({ }^{13} \mathrm{C} /{ }^{12} \mathrm{C}\right)$ of consumers and the 2 main food sources in streamsbenthic algae and terrestrial leaves-has advanced our understanding of stream organic matter process-

\footnotetext{
${ }^{1}$ Present address: Australian Rivers Institute, Griffith University, Nathan Campus, Nathan, Queensland, 4111, Australia. E-mail: t.jardine@griffith.edu.au

2 E-mail addresses: kiddk@unbsj.ca

3 cunjak@unb.ca
}

ing by consumers by showing the importance of terrestrial inputs in temperate headwaters and the dominance of algae in tropical ecosystems (e.g., Doucett et al. 1996, Lau et al. 2009). This approach allows estimation of the contribution of the 2 food sources to animal diets because of limited fractionation of ${ }^{13} \mathrm{C} /{ }^{12} \mathrm{C}$ during trophic transfer $(\sim 0.4 \%$; Post 2002). However, the technique is limited because of considerable variability in ${ }^{13} \mathrm{C} /{ }^{12} \mathrm{C}$ of periphytic algae that often overlaps the ${ }^{13} \mathrm{C} /{ }^{12} \mathrm{C}$ of terrestrial organic matter (France 1995) and makes assigning source proportions (i.e., relative importance of sources) to consumers difficult except in situations where the 2 sources are extremely distinct (Rosenfeld and Roff 1992, Jardine et al. 2008a).

Stable isotope ratios of $\mathrm{H}\left({ }^{2} \mathrm{H} /{ }^{1} \mathrm{H}\right.$ or $\left.\mathrm{D} / \mathrm{H}\right)$ show some promise as an alternative or complementary means to trace organic matter originating from 
autochthonous or allochthonous pathways through stream food webs. Theoretically, transpiration by land plants should enrich leaves in D because the lighter isotope is preferentially lost to the atmosphere (e.g., Walker and Brunel 1990), a phenomenon not observed in aquatic autotrophs. Given the broad range in D/H observed on a global scale (Bowen et al. 2005) and recent improvements in analytical capabilities for this element in organic tissues (Wassenaar and Hobson 2000), $\delta$ D might provide a stronger signalto-noise ratio (variability among sources relative to variability within sources) than other more traditionally measured isotopes, such as $\delta^{13} \mathrm{C}$ (Becker 2005, Jardine and Cunjak 2005). Thus, measures of $\delta \mathrm{D}$ in stream organisms might allow estimation of dietary source proportions at more sites, and with potentially better resolution, than has been achieved with $\delta^{13} \mathrm{C}$ (Phillips and Gregg 2001). Doucett et al. (2007) reported wide separation in $\delta \mathrm{D}$ between terrestrial and aquatic food sources in the Colorado River, USA, at relatively dry (xeric) sites. What remains to be determined is the applicability of the technique in more mesic environments where evapotranspiration losses in land plants might not be as great. Also, little is known about the isotopic relationship between an animal and its diet (diet-tissue fractionation) for $\mathrm{D}$. Given the variability observed in diet-tissue fractionation for $\delta^{13} \mathrm{C}( \pm 0.9 \mathrm{SD}$; Post 2002) and its effect on mixing-model outcomes (Phillips and Gregg 2001), a low and consistent $\delta \mathrm{D}$ diet-tissue fractionation would be a positive attribute in its use as a source tracer in aquatic systems.

The purpose of our study was to evaluate the use of $\mathrm{D}$ as a food source tracer in streams in a temperate mesic environment. We sought to determine if $\mathrm{D}$ could provide additional information (i.e., greater resolution, more sites where food sources were distinct) to that obtained by using $\delta^{13} \mathrm{C}$. We sampled instream primary producers (biofilm) and riparian vegetation (alder [Alnus spp.] leaves) from 31 sites in New Brunswick, Canada, and measured $\delta \mathrm{D}$ and $\delta^{13} \mathrm{C}$ on the samples. We also analyzed $\delta \mathrm{D}$ and $\delta^{13} \mathrm{C}$ of benthic invertebrates at a subset of sites to determine if values fell within the range delineated by the 2 food sources. Last, in the laboratory, we analyzed the $\delta \mathrm{D}$ of 2 consumers common in streams (brook trout [Salvelinus fontinalis] and water striders [Aquarius remigis]) and their diets to determine diet-tissue $\delta \mathrm{D}$ fractionation.

\section{Methods}

We sampled 31 sites in New Brunswick, Canada, in August and September 2005 and 2006 (Table 1). Sites were located in 6 major drainages: Restigouche River (lat $47.59^{\circ} \mathrm{N}$, long $66.46^{\circ} \mathrm{W}$ ), Renous River (lat $46.49^{\circ} \mathrm{N}$, long $65.47^{\circ} \mathrm{W}$ ), Little Southwest Miramichi River (lat $46.57^{\circ} \mathrm{N}$, long $65.50^{\circ} \mathrm{W}$ ), Newcastle Creek (lat $46.04^{\circ} \mathrm{N}$, lat $65.59^{\circ} \mathrm{W}$ ), Cains River (lat $46.40^{\circ} \mathrm{N}$, long $65.47^{\circ} \mathrm{W}$ ), and Salmon River (lat $46.06^{\circ} \mathrm{N}$, long $65.55^{\circ} \mathrm{W}$ ).

At each site, we collected samples of biofilm and terrestrial leaves (the 2 main sources of organic matter for consumers). Phytoplankton was unlikely to be present in any of these sites because they were shallow and fast-flowing. Macrophytes were rare, and moss was unlikely to be important in the diet of aquatic consumers because sufficient biofilm was present. Thus, we considered biofilm the best representative of instream production. We collected 3 biofilm samples at each site by scraping $\geq 3$ rocks/ sample with a toothbrush. We removed 3 samples of fresh leaves from the dominant species (alder) growing in the riparian zone of the stream. Alder are not the only species of tree in the riparian zone of these streams, but they are most likely to contribute to aquatic food webs because they fix $\mathrm{N}$ and have correspondingly low $\mathrm{C} / \mathrm{N}(19.5 \pm 2.7 \mathrm{SD})$. We stored samples on ice until we returned to the laboratory, where we freeze-dried the samples and ground them to a homogenous powder for isotope analysis.

We collected benthic invertebrates with D-frame kick nets from a subset of the sites $(n=6$ sites in the Cains River, Little Southwest Miramichi River, and Restigouche River). Isotope ratios of guts and body tissues of stream invertebrates are highly correlated (Jardine et al. 2005). Therefore, we held invertebrates for only $\sim 6 \mathrm{~h}$ to clear their guts before we freezedried and ground them to a homogeneous powder for isotope analysis. Invertebrates included dragonflies (Aeshnidae, $n=2$ pooled samples; Gomphidae, $n=7$ pooled samples), stoneflies (Perlidae, $n=3$ pooled samples), and mayflies (Heptageniidae, $n=4$ pooled samples). We did not extract lipids from these samples.

We reared samples of consumers on a consistent laboratory diet and analyzed them for D to measure diet-tissue fractionation. We sampled white muscle tissue from brook trout $(n=6$, average fork length $=$ $70 \mathrm{~mm}$ ) that were raised from the alevin stage on a consistent diet of pellets $(n=3$, representing 1 each of 3 pellet sizes) (Jardine et al. 2008a). Trout mass increased by several orders of magnitude after we began feeding them pellets, so we assumed they were in isotopic equilibrium with their diet. We collected water striders from a stream and reared them on crickets (Gryllidae); a subset of these striders and crickets were sampled ( $n=3$ each) after $72 \mathrm{~d}$ of rearing. These striders also were in isotopic equilib- 
TABLE 1. Locations and sizes of stream sites in New Brunswick, Canada, and mean ( \pm SD) stable H isotope ratios of biofilm and alder at those sites. $\delta \mathrm{D}=$ stable $\mathrm{H}$ isotope ratio $(\mathrm{D} / \mathrm{H})$.

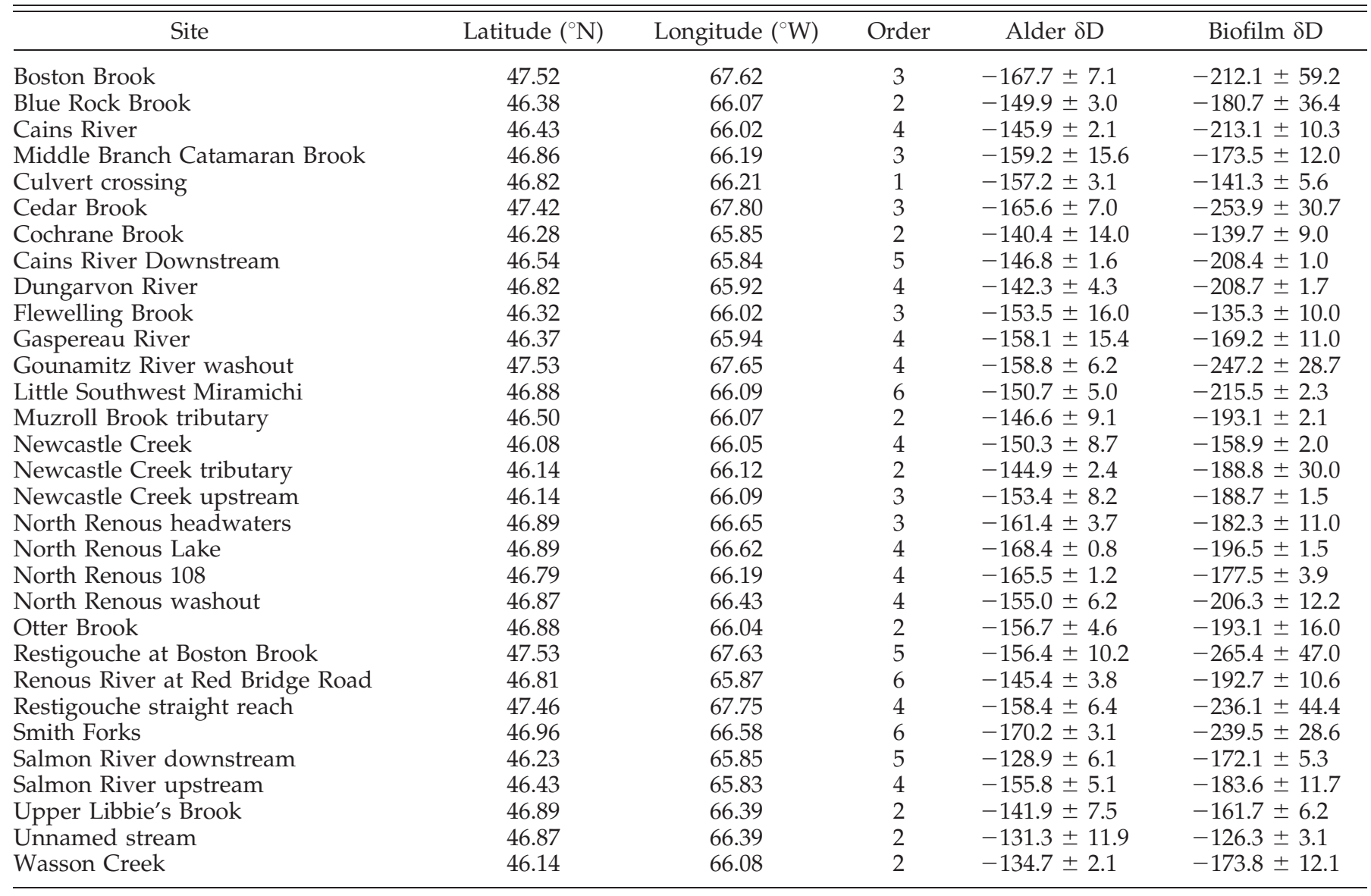

rium with the cricket diet because their $\mathrm{C}$ and $\mathrm{N}$ isotope ratios reached a steady state after an increase in mass by striders of $\sim 400 \%$ over the course of the experiment (Jardine et al. 2008b). We assumed similar elemental incorporation rates for $\mathrm{H}$ as for $\mathrm{C}$ and $\mathrm{N}$. These laboratory samples were processed as described above for stable isotope analysis. After initial analysis for $\delta \mathrm{D}$, we suspended tissue in chloroformmethanol solution to extract lipids (Logan et al. 2008). We redried the samples and analyzed them for $\delta \mathrm{D}$.

We used a comparative equilibration technique with standards of known $\mathrm{H}$ isotope ratios to account for the potential exchange of $\mathrm{H}$ between air and tissues and its effects on $\delta \mathrm{D}$ analysis (Wassenaar and Hobson 2000, 2003). We put $\sim 0.3 \mathrm{mg}$ of each of 3 standards (Bowhead Whale Baleen [BWB], Chicken Feather [CFS], and Cow Hoof [CHS]) in silver capsules, placed them beside samples on a bench top in the laboratory, and allowed them to equilibrate with local water vapor for $\geq 72 \mathrm{~h}$. We loaded samples and standards into a zero-blank autosampler. After pyrolysis in a thermal conversion/elemental analyzer
(TC/EA; Thermo Finnigan, Bremen, Germany) and analysis in a Delta XP mass spectrometer (Thermo Finnigan), we adjusted all values to bring BWB, CFS, and CHS to $\delta \mathrm{D}$ values of $-108 \%,-147 \%$, and $-187 \%$, respectively (Wassenaar and Hobson 2000, 2003). This technique standardizes all values relative to the Vienna Standard Mean Ocean Water (VSMOW) scale. To monitor precision, we analyzed a single sample (homogenized aquatic moss grown in laboratory conditions) every time samples were run. These samples yielded $\delta \mathrm{D}=-91.7 \pm 3.3 \%$ (SD; $n=6)$. BWB, CFS, and CHS had values of $-108.4 \pm 1.5 \%$ ( $n$ $=63),-146.5 \pm 1.8 \%$ o $(n=84)$, and $-187.1 \pm 2.1 \%$ o $(n$ $=62$ ), and a commercially available keratin standard yielded $\delta \mathrm{D}=-116.2 \pm 2.6 \%$ ( $(n=31)$.

For analysis of $\mathrm{C}$ isotope ratios, we weighed $\sim 1.0 \mathrm{mg}$ (plants) or $\sim 0.2 \mathrm{mg}$ (animals) of dried powdered samples into tin capsules and combusted them in a NC2500 elemental analyzer (Carlo Erba, Milan, Italy). Resultant gases were delivered via continuous flow to a Thermo Finnigan Delta XP mass spectrometer. We used International Atomic Energy 
Agency (IAEA) standards $\mathrm{CH} 6, \mathrm{CH} 7, \mathrm{~N} 1$, and $\mathrm{N} 2$ to calibrate data to the Vienna Peedee Belemnite (VPDB) scale. We monitored accuracy and precision with a commercially available standard (acetanilide; $\delta^{13} \mathrm{C}=$ $-33.60 \pm 0.12 \%, n=59$; Elemental Microanalysis Ltd., Okehampton, UK; Jardine et al. 2008b).

We use the term signal to describe the average difference in $\delta \mathrm{D}$ or $\delta^{13} \mathrm{C}$ between the 2 food sources (biofilm and alder) within sites. We use the term noise to describe the variation of each food source within each site. Noise encompasses variability from individual organisms, sample heterogeneity, and analytical error (Jardine and Cunjak 2005). We calculated signal-to-noise ratio as:

$$
\begin{aligned}
& \left(\left[\sum \delta X_{\text {biofilm }}-\delta X_{\text {alder }}\right] / \text { no. of sites }\right) \\
& \quad \div\left(\sum \mathrm{SD}_{\text {biofilm }} \text { or } \mathrm{SD}_{\text {alder }} / \text { no. of sites }\right)
\end{aligned}
$$

where $\mathrm{X}$ is ${ }^{13} \mathrm{C}$ or $\mathrm{D}$ and SD is the standard deviation for the respective isotope analysis. We considered food sources to be isotopically distinct within a site if there was no overlap of mean \pm 1 SD between sources. This criterion is similar to that used by Jardine et al. (2008b), where mixing models for water striders were used only if food sources differed by $>2 \%$. The $\delta^{13} \mathrm{C}$ data used in that study are the same data presented here.

We used a general linear model analysis of variance (GLM-ANOVA) with source (alder and biofilm; fixed factor) and site (random factor) to test for differences in $\delta \mathrm{D}$ between sources. We used regression analyses to test for an increase in the difference between biofilm and alder isotope ratios with increasing stream size (order).

For benthic invertebrates analyzed for $\delta \mathrm{D}$ and $\delta^{13} \mathrm{C}$, we used simple mixing models to calculate $\%$ aquatic $\mathrm{H}$ and $\%$ aquatic $\mathrm{C}$ in the diet as:

$$
\begin{aligned}
\% \text { aquatic } & =\left(\delta X_{\text {consumer }}-\delta X_{\text {terrestrial }}\right) \\
& \div\left(\delta X_{\text {aquatic }}-\delta X_{\text {terrestrial }}\right) \times 100
\end{aligned}
$$

where $\mathrm{X}$ is ${ }^{13} \mathrm{C}$ or $\mathrm{D}$ and terrestrial and aquatic endmembers are site-specific alder and biofilm isotope ratios, respectively. We assumed no trophic fractionation for either $\delta^{13} \mathrm{C}$ or $\delta \mathrm{D}$ in these models. We present values $>100 \%$ and $<0 \%$ as raw values (rather than setting them to 100 and 0 , respectively) to illustrate the variation in source proportions for both $\delta^{13} \mathrm{C}$ and $\delta \mathrm{D}$. These values simply reflect consumer $\delta^{13} \mathrm{C}$ or $\delta \mathrm{D}$ that was outside the range of sources.

We tested for differences in $\delta \mathrm{D}$ between laboratoryreared consumers and their diet with a 1-way

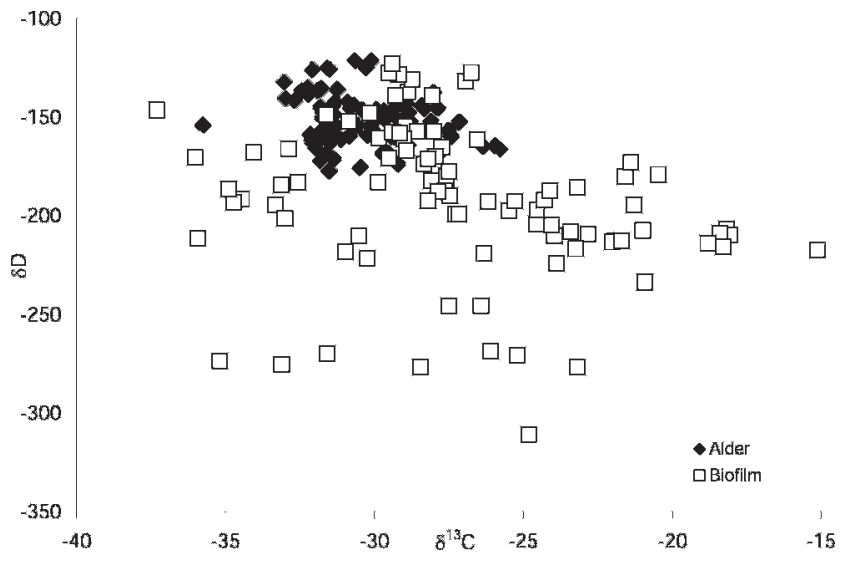

FIG. 1. $\quad H(\delta D)$ and $C\left(\delta^{13} C\right)$ stable isotope ratios of biofilm and alder leaves from streams in New Brunswick, Canada.

ANOVA followed by the Bonferroni test to discriminate among types (consumer and diet) and treatments (lipid-extracted and nonextracted). We analyzed the 2 consumer-diet pairings separately.

\section{Results}

Biofilm had a much larger range in $\delta \mathrm{D}$ and was generally depleted in $\mathrm{D}$ relative to alder, whereas $\delta^{13} \mathrm{C}$ in biofilm also had a broader range than alder but with a similar mean value (Fig. 1). The site and source interaction term for $\delta \mathrm{D}$ was statistically significant $(F$ $=5.33, \mathrm{df}=30, p<0.001$ ), largely because biofilm $\delta \mathrm{D}$ was similar or elevated relative to alder $\delta \mathrm{D}$ at 4 sites (Table 1). Variation within and between food sources was much higher for $\delta \mathrm{D}$ than for $\delta^{13} \mathrm{C}$, but the signalto-noise ratios for the 2 elements were similar (Table 2). At 16 sites, both $\delta^{13} \mathrm{C}$ and $\delta \mathrm{D}$ differed between food sources. At 11 sites, only 1 of the 2 elements differed between food sources. Only at 4

TABle 2. Comparison of the efficacy of $\delta \mathrm{D}$ and $\delta^{13} \mathrm{C}$ in discriminating between food sources in 31 streams in New Brunswick, Canada. Signal-to-noise ratio is variability (represented by standard deviation [SD]) within sources vs variability between sources. $\delta \mathrm{D}=$ stable $\mathrm{H}$ isotope ratio $(\mathrm{D} / \mathrm{H})$.

\begin{tabular}{lrl}
\hline \hline \multicolumn{1}{c}{ Measure of discrimination } & $\delta^{13} \mathrm{C}$ & $\delta \mathrm{D}$ \\
\hline No. of sites where food sources could be & & \\
$\quad$ distinguished from each other & 20 & 23 \\
Average difference between food sources (\%) & 4.0 & 41.7 \\
Average SD within sites for biofilm & 1.6 & 15.1 \\
Average standard deviation within sites for & & \\
$\quad$ alder & 0.7 & 6.5 \\
Signal-to-noise ratio for biofilm & 2.5 & 2.8 \\
Signal-to-noise ratio for alder & 5.7 & 6.4 \\
\hline
\end{tabular}




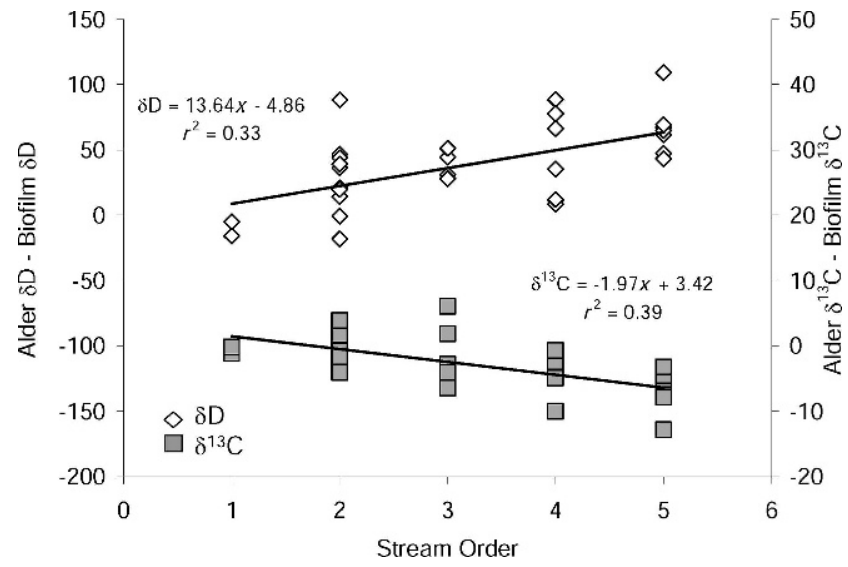

FIG. 2. The difference between alder and biofilm mean $\delta \mathrm{D}$ (stable $\mathrm{H}$ isotope ratio; $\mathrm{D} / \mathrm{H}$ ) and alder and biofilm mean $\delta^{13} \mathrm{C}$ as functions of stream order. Best-fit equations are shown for both isotopes.

sites did neither $\delta^{13} \mathrm{C}$ nor $\delta \mathrm{D}$ differ between food sources. Food sources were less isotopically distinct in small headwater streams than in larger rivers. Regressions of the difference between biofilm and alder isotope ratios vs stream order were significant for both $\delta^{13} \mathrm{C}\left(r^{2}\right.$ $=0.42, n=31, p<0.001)$ and $\delta \mathrm{D}\left(r^{2}=0.27, n=31, p=\right.$ 0.003) (Fig. 2).

Mixing models suggested that $\delta \mathrm{D}$ can be confounded by nondietary influences or diet-tissue fractionation. $\delta^{13} \mathrm{C}$ of invertebrate consumers fell within the bounds of the 2 food sources (with 1 exception) and yielded estimates of \% aquatic $C$ between 0 and $100 \%$, but $\delta \mathrm{D}$ of the same consumers was often outside the bounds of the 2 sources (Fig. 3). Consumers were often enriched in D relative to the 2 food sources. At Otter Brook, consumers were isotopically out of phase with their food sources. $\delta^{13} \mathrm{C}$ of heptageniid mayflies $(-39.0 \%)$ was far lower than $\delta^{13} \mathrm{C}$ of biofilm $(-33.9 \%)$ at the site and yielded an estimate of $\%$ aquatic $\mathrm{C}=$ $241 \%$, and $\delta \mathrm{D}$ of aeshnid dragonflies $(-108.5 \%)$ was much higher than $\delta \mathrm{D}$ of alder $(-156.7 \%$ ) or biofilm $(-193.1 \%)$.

$\delta \mathrm{D}$ differed significantly between laboratory-reared consumers and their diets (trout vs pellets: $F=121.7$, $\mathrm{df}=3, p<0.001$; striders vs crickets: $F=204.6, \mathrm{df}=$ $3, p<0.001$; Fig. 4). $\delta \mathrm{D}$ of trout was higher than that of their pellet diet, but this difference disappeared after lipid extraction (Fig. 4). $\delta \mathrm{D}$ of water striders was lower than that of their cricket diet, but this difference disappeared after lipid extraction (Fig. 4). Lipid extraction caused large changes in $\delta \mathrm{D}$ of the pellets (average change $=46.1 \pm 4.3 \% \mathrm{SD}$ ) and water striders (average change $=56.0 \pm 2.4 \% \mathrm{SD}$ ). Pellets and water striders were rich in lipids (indicated by high $\mathrm{C} / \mathrm{N}$ of nonextracted samples; pellet $\mathrm{C} / \mathrm{N}=6.0 \pm 0.2 \mathrm{SD}$,

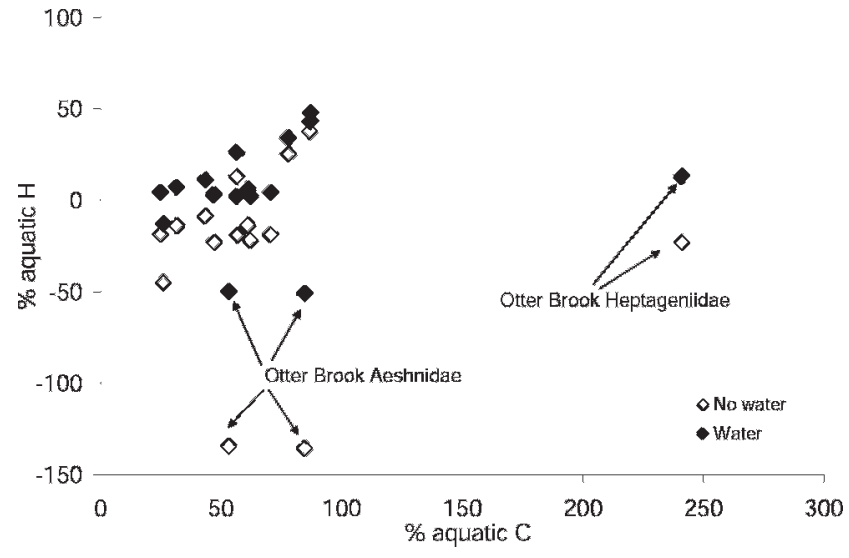

FIG. 3. Estimates of $\%$ aquatic $\mathrm{H}$ and $\%$ aquatic $\mathrm{C}$ (calculated from mixing models for $\delta \mathrm{D}$ [stable $\mathrm{H}$ isotope ratio; $\mathrm{D} / \mathrm{H}]$ and $\delta^{13} \mathrm{C}$ respectively) for benthic invertebrates in New Brunswick, Canada, streams before and after accounting for the potential contribution of water to tissue $\mathrm{H}$. Values $<0$ and $>100$ occur when consumer ratios fall outside the range of the 2 food sources.

strider $\mathrm{C} / \mathrm{N}=5.4 \pm 0.5 \mathrm{SD}$; Jardine et al. 2008b) (Post et al. 2007, Logan et al. 2008). Lipid extraction had less effect on the $\delta \mathrm{D}$ of trout muscle (average change $=$ $12.7 \pm 3.5 \%$ SD) and crickets (average change $=26.2$ $\pm 3.5 \% \mathrm{SD}$ ). Both of these tissues had low lipid levels (indicated by low $\mathrm{C} / \mathrm{N}$ prior to extraction; trout $\mathrm{C} / \mathrm{N}$ $=3.5 \pm 0.1 \mathrm{SD}$, cricket $\mathrm{C} / \mathrm{N}=3.3 \pm 0.1 \mathrm{SD}$ ).

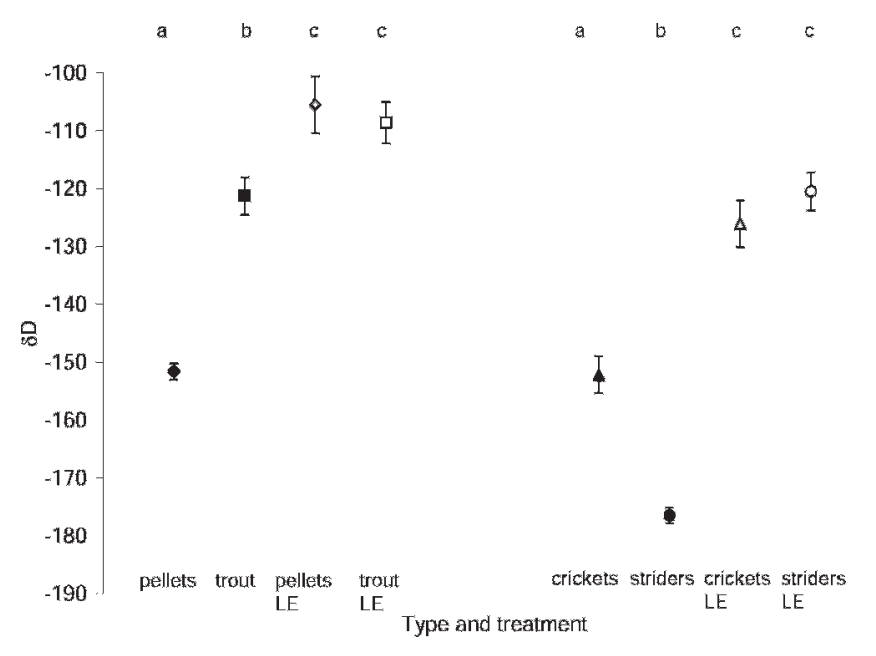

Fig. 4. Mean ( \pm 1 SD) stable $H$ isotope ratios of laboratory-reared consumers and their diets before and after lipid extraction (LE). Trout (Salvelinus fontinalis) were fed a formulated pellet diet and water striders (Aquarius remigis) were fed crickets (Gryllidae) sold commercially as a pet food. Type refers to consumer vs diet, and treatment refers to before or after LE. Different letters indicate statistically significant differences among type-treatment pairs. 


\section{Discussion}

Our results suggest that $\delta \mathrm{D}$ might be useful as a complementary, but not an alternative, method of tracing organic matter sources to consumers in temperate streams. $\delta \mathrm{D}$ differed significantly between the 2 food sources in our streams, but these differences were not as large as those reported previously for arid environments (Doucett et al. 2007). Furthermore, mixing models with $\delta D$ provided values for consumers that were often outside the bounds of the 2 food sources, a result that suggests unaccounted variability either in sources or in consumers. Moreover, laboratory trials indicated that lipids could strongly interfere with interpretation of consumer-diet relationships on the basis of $\delta \mathrm{D}$.

Signal-to-noise ratios indicate the potential resolution of an isotope of interest. D has higher within-site variability in a food source (average SD within sites for biofilm was $\sim 15 \%$ ) and poorer precision on modern mass spectrometers (typically $\sim 3 \%$ SD for a given organic sample measured repeatedly; Tuross et al. 2008) than does ${ }^{13} \mathrm{C}$. However, the wide separation of $\delta \mathrm{D}$ values between food sources helps overcome these limitations and places $\delta \mathrm{D}$ on par with $\delta^{13} \mathrm{C}$ as a tool with which to measure reliance on aquatic vs terrestrial organic matter in streams (Doucett et al. 2007). Furthermore, the weak correlation between $\delta^{13} \mathrm{C}$ and $\delta \mathrm{D}$ in source material (biofilm $r=-0.24$, alder $r=-0.24$; Fig. 1) suggests that biogeochemical controls on the 2 elements are different. Thus, $\delta^{13} \mathrm{C}$ and $\delta \mathrm{D}$ provide 2 independent tracers when used together. This feature could reduce the need to eliminate sites because of poor separation between sources, as in Jardine et al. (2008b), where 43 of 88 stream sites were excluded because aquatic and terrestrial $\delta^{13} \mathrm{C}$ were not sufficiently distinct. However, the broader utility of $\delta \mathrm{D}$ is questionable, particularly if $\delta \mathrm{D}$ of aquatic vegetation varies systematically with stream physicochemical variables, as Finlay (2004) showed for $\delta^{13} \mathrm{C}$ and water velocity and $\mathrm{CO}_{2}$ availability.

Theory suggests that evapotranspiration should control terrestrial $\delta \mathrm{D}$ (Pendall et al. 2005), but evapotranspiration might not be the key mechanism underlying differences in $\delta \mathrm{D}$ between terrestrial and aquatic plants. We expected that terrestrial vegetation in our moderately mesic study region (mean annual precipitation $=1000-1500 \mathrm{~mm}$ ) would be far less enriched in $\mathrm{D}$ than was terrestrial vegetation sampled by Doucett et al. (2007) near the arid Colorado River (mean annual precipitation $<500 \mathrm{~mm}$ ). Instead, $\delta \mathrm{D}$ values for terrestrial material in our study (mean for all data $=-153.8 \pm 1.3 \%$ SE) were similar to those of riparian plants sampled by Doucett et al. (2007) (mean for all data $=-147.2 \pm 4.8 \%$ SE). However, $\delta \mathrm{D}$ of biofilm in our study (mean for all data $=-193.7 \pm$ $3.9 \%$ SE) differed from $\delta \mathrm{D}$ of aquatic food sources reported by Doucett et al. (2007) (mean for all data = $-245.5 \pm 8.4 \%$ SE). These results suggest that characteristics of the water body being analyzed (e.g., chemistry and $\delta \mathrm{D}$ of water), the effects of those variables on $\delta \mathrm{D}$ of aquatic vegetation, and the type of aquatic vegetation present (species and growth forms), rather than climatic characteristics that probably influence terrestrial $\delta \mathrm{D}$, will determine whether $\delta \mathrm{D}$ of aquatic and terrestrial plants differ.

Differences in leaf water retention among species in the 2 regions might have obscured differences in water loss and subsequent isotopic enrichment during transpiration. Doucett et al. (2007) sampled willow (Salix spp.), mesquite (Prosopis spp.), and tamarisk (Tamarix spp.). Willow and mesquite have evapotranspiration rates similar to alder $(0.4-0.9 \mathrm{~m} / \mathrm{y}$; Herbst et al. 1999, Shafroth et al. 2005). Evapotranspiration rates as high as $3 \mathrm{~m} / \mathrm{y}$ have been reported for tamarisk, but other studies have found lower values (Shafroth et al. 2005). Assuming equal evapotranspiration rates, $\delta \mathrm{D}$ of terrestrial plants should reflect $\delta \mathrm{D}$ of annual precipitation in the region where the plants grew. $\delta \mathrm{D}$ of annual precipitation in New Brunswick (Canada) (our study) and Nevada/Arizona (USA) (Doucett et al. 2007) is relatively similar (www. waterisotopes.org; Bowen et al. 2005). Ultimately, the $\delta \mathrm{D}$ value of riparian plants will be determined by their proportional use of deep groundwater reserves (Dawson and Ehleringer 1991) vs river water, which could include water from distal locations with different $\delta \mathrm{D}$. This effect, coupled with the effects of evapotranspiration, could cause riparian plant $\delta \mathrm{D}$ to deviate from the $\delta \mathrm{D}$ of local rainfall.

Analyses of laboratory-reared consumers suggested that lipids might interfere with interpretation of $\delta \mathrm{D}$ values from wild animal populations. Diet-tissue fractionation before lipid extraction was $\sim 30 \%$ for laboratory-reared trout and $\sim-25 \%$ for laboratoryreared striders, but after lipid extraction, we observed no discernable difference in $\delta \mathrm{D}$ between these consumers and their diet, a result similar to recent findings by Solomon et al. (2009). Other laboratory studies of animals reared on constant diets have found large variation $(>100 \%)$ in $\delta \mathrm{D}$ among tissues that was caused, at least in part, by differences in lipid content (Hobson et al. 1999, Tuross et al. 2008). Much of the observed variation in $\delta^{13} \mathrm{C}$ diet-tissue fractionation (Post 2002) also might be a consequence of the confounding influence of lipids, and models have been developed to correct for this variability 
(e.g., Post et al. 2007, Logan et al. 2008). More detailed laboratory studies might allow development of similar models to correct $\delta \mathrm{D}$ for lipids. However, a simpler solution might be to extract lipids from all tissues before analysis, especially given that, unlike $\delta^{13} \mathrm{C}$, which can be corrected with $\mathrm{C} / \mathrm{N}$ generated during analysis, no easy method presently exists for estimating lipid content of tissue being analyzed for $\delta \mathrm{D}$.

Lipids also interfere with analytical capacity for $\delta \mathrm{D}$. Lipids largely contain $\mathrm{C}-\mathrm{H}$ bonds that are theoretically nonexchangeable (Schimmelmann et al. 1999), so lipid-rich tissues have far less $\mathrm{H}$ available to exchange with ambient water vapor in the laboratory than does lipid-poor tissue. This difference would confound analyses in which keratin standards are used to calibrate data to the VSMOW scale because these standards are designed for organic samples with 20\% exchangeable $\mathrm{H}$ (Wassenaar and Hobson 2000, 2003). Equilibration of lipid-rich tissues (with far lower exchangeable $\mathrm{H}$ ) with the keratin standards would over-correct the data and would introduce error into $\delta \mathrm{D}$ measurements. Benthic invertebrates synthesize lipids, and some taxa have high \% lipid (Meier et al. 2000). Thus, much of the observed variation in \% aquatic $H$ in our study could have been caused by the variable lipid content of the organisms themselves.

In addition to analytical challenges presented by lipids, lipids also can affect $\delta \mathrm{D}$ values directly. Similar to discrimination against ${ }^{13} \mathrm{C}$ during de novo lipid synthesis (DeNiro and Epstein 1977), fractionation against D also occurs during this process (Sessions et al. 1999, Chikaraishi et al. 2004). This fractionation could influence $\delta \mathrm{D}$ in invertebrates and other taxa that synthesize lipids. Controlled studies also suggest that a strong linear relationship exists between algal lipid $\delta \mathrm{D}$ and $\delta \mathrm{D}$ of surrounding water (Zhang and Sachs 2007), so the observed differences in biofilm $\delta D$ between our study and that of Doucett et al. (2007) probably were the result of the unique biogeochemistry and resultant $\delta \mathrm{D}$ values of the waters in which the biofilm was growing. However, variation in $\delta \mathrm{D}$ also exists among lipid classes (Zhang and Sachs 2007), so the bulk $\delta$ D signature of algae will represent an amalgamation of several factors, including analytical error introduced by reduced $\mathrm{H}$ exchange relative to keratin standards.

Direct uptake of water to the body pool also might have contributed to incorrect estimates of $\%$ aquatic H. Hobson et al. (1999) reported that $\sim 20 \%$ of the $\mathrm{H}$ in quail blood, muscle, and liver was from ingested water, not from diet. The average value for $\omega$ (the contribution of water to tissue $\mathrm{H}$ ) is $0.17 \pm 0.12 \mathrm{SD}$ for aquatic consumers (Solomon et al. 2009). We do not have data for water for our rivers, but we can estimate $\delta \mathrm{D}$ of river water as being between -100 and $-60 \%$ based on continental maps by Kendall and Coplen (2001). We used the maximum value for water $(-60 \%)$ and the average value of $\omega(0.17$; Solomon et al. 2009), to recalculate source proportions using the formula $\delta \mathrm{D}_{\text {consumer }}=\omega \times \delta \mathrm{D}_{\text {water }}+(1-\omega) \times(\mathrm{t} \times$ $\left.\left.\delta \mathrm{D}_{\text {terrestrial }}\right)+(1-\mathrm{t}) \times \delta \mathrm{D}_{\text {biofilm }}\right)$, where $\mathrm{t}$ is the proportion of terrestrial $\mathrm{H}$ in the diet (Solomon et al. 2009), and solved with least-squares iterations. These calculations yielded source $\mathrm{H}$ proportions that were far more constrained than our original values, with only 3 values outside the range of isotope values for food sources (vs 11 when $\mathrm{H}$ uptake from water is ignored; Fig. 3). We applied the same calculations to our laboratory data and found a slight negative diettissue fractionation for trout (trout $\delta \mathrm{D}$ corrected for water contribution $=-118.9 \pm 3.6 \%$ SD compared to pellet diet $\delta \mathrm{D}=-105.5 \pm 4.9 \% \mathrm{SD}, F=21.9$, $\mathrm{df}=1, p$ $=0.002)$, but statistical equivalence between $\delta \mathrm{D}$ of water strider and their cricket $\operatorname{diet}(F=2.5, \mathrm{df}=1, p$ $=0.188$ ).

Heptageniids and aeshnids living in Otter Brook had $\delta^{13} \mathrm{C}$ and $\delta \mathrm{D}$ values that corresponded poorly with available food sources. Otter Brook is a small, groundwater-fed stream that remains ice-free during the winter. It has biofilm and invertebrates that are depleted in ${ }^{13} \mathrm{C}(<-32 \%$; Cunjak et al. 2005), and the $\delta^{13} \mathrm{C}$ value for heptageniids observed in our study $(-39 \%$ ) was only $2 \%$ below the lowest observed value for biofilm from the system. Therefore, trophic fractionation could account for the high \% aquatic $\mathrm{H}$ estimate for this taxon because consumers can be depleted in ${ }^{13} \mathrm{C}$ by as much as $3 \%$ relative to their diet (Post 2002). However, aeshnids require a different explanation. Their $\delta \mathrm{D}$ values were $\sim 50 \%$ o higher than the most D-enriched food source (terrestrial matter) at the site. This taxon might have a high contribution to tissue $\mathrm{H}$ from water. If we use the maximum value of $\omega$ (0.39; Solomon et al. 2009) and determine source proportions for aeshnids from Otter Brook, we find that $\%$ aquatic $\mathrm{C}=-11 \%$, a far more reasonable value than values calculated with no contribution from water $(-135 \%$ aquatic $H)$ and with the average $(0.17)$ contribution from water $(-50 \%$ aquatic $\mathrm{H})$.

At 4 sites where alder and biofilm $\delta \mathrm{D}$ were not distinct, deposition of terrestrially derived particulate organic matter might have caused contamination of biofilm samples. The difference in isotope ratios (for both $\delta \mathrm{D}$ and $\delta^{13} \mathrm{C}$ ) between food sources approached 0 in the smallest streams (orders 1-2), possibly reflecting the larger input of terrestrial material into these small streams (Wallace et al. 1997). This problem 
could be overcome by using colloidal silica to separate algae from terrestrial detritus (Hamilton et al. 2005) to provide better end-members in mixing models when using $\delta \mathrm{D}$ and $\delta^{13} \mathrm{C}$.

A final consideration when evaluating the occasional mismatch between $\delta \mathrm{D}$ of consumers and food sources is conditioning of terrestrial leaves. Bacterial breakdown of leaf matter once it reaches the stream might result in isotopic fractionation of $\delta \mathrm{D}$. A similar phenomenon has been observed for $\delta^{13} \mathrm{C}$ (Finlay 2001). We sampled terrestrial material as fresh leaves from the riparian zone, and the source of $\mathrm{H}$ for bacteria colonizing leaf matter in the stream is unknown. Thus, our $\delta \mathrm{D}$ values for this food source could have been slightly different from that available to consumers as detritus. However, changes in $\delta^{13} \mathrm{C}$ with conditioning are relatively small $(\sim 2 \%$ change from fresh material to fine particulate organic matter; Finlay 2001), so changes in $\delta D$ during conditioning are likely to have introduced a small amount of error compared to other factors discussed above.

Our data expand the potential applicability of $\delta \mathrm{D}$ as a source tracer in aquatic systems, but they also highlight some of the challenges of using this isotope in a relatively new manner. The contribution of ambient water to total body $\mathrm{H}$ of aquatic consumers is now better understood (Solomon et al. 2009), but our study illustrates that more work is needed to understand the effects of lipid content on $\delta \mathrm{D}$, both from a physiological (fractionation) and technological (exchangeable $\mathrm{H}$ ) perspective. If these and other unknowns continue to generate uncertainty, the use of models that incorporate this uncertainty into source proportion estimates (e.g., Moore and Semmens 2008) might ultimately aid in the further expansion of the technique.

\section{Acknowledgements}

We thank L. Wassenaar and R. Doucett for providing calibration standards for $\mathrm{D}$, and A. McGeachy, C. Paton, and M. Savoie for isotope analysis. Comments from 3 referees helped improve the presentation of this manuscript. Funding for this work was provided by the New Brunswick Environmental and Wildlife Trust Funds, the Natural Sciences and Engineering Research Council, and the Canada Research Chairs Program.

\section{Literature Cited}

BECKER, J. S. 2005. Recent developments in isotope analysis by advanced mass spectrometric techniques. Plenary lecture. Journal of Analytical Atomic Spectrometry 20: 1173-1184.
Bowen, G. J., L. I. WassenaAr, And K. A. Hobson. 2005. Global application of stable hydrogen and oxygen isotopes to wildlife forensics. Oecologia (Berlin) 143:337-348.

Chikaraishi, Y., H. Naraoka, And S. Poulson. 2004. Carbon and hydrogen isotopic fractionation during lipid biosynthesis in a higher plant (Cryptomeria japonica). Phytochemistry 65:323-330.

Cunjak, R. A., J.-M. Roussel, M. A. Gray, J. P. Dietrich, D. F. Cartwright, K. R. Munkittrick, and T. D. Jardine. 2005. Using stable isotope analysis with telemetry or markrecapture data to identify fish movement and foraging. Oecologia (Berlin) 144:636-646.

DAwsOn, T. E., AND J. R. EHLERINGER. 1991. Streamside trees that do not use stream water. Nature 350:335-337.

DeNiro, M. J., and S. Epstein. 1977. Mechanism of carbon isotope fractionation associated with lipid synthesis. Science 197:261-263.

Doucett, R. R., J. C. Marks, D. W. Blinn, M. Caron, and B. A. Hungate. 2007. Measuring terrestrial subsidies to aquatic food webs using stable isotopes of hydrogen. Ecology 88:1587-1592.

Doucett, R. R., G. Power, D. R. Barton, R. J. Drimmie, and R. A. CunjaK. 1996. Stable isotope analysis of nutrient pathways leading to Atlantic salmon. Canadian Journal of Fisheries and Aquatic Sciences 53:2058-2066.

FinLAY, J. C. 2001. Stable-carbon-isotope ratios of river biota: implications for energy flow in lotic food webs. Ecology 82:1052-1064.

FinLAY, J. C. 2004. Patterns and controls of lotic algal stable carbon isotope ratios. Limnology and Oceanography 49: 850-861.

France, R. 1995. Critical examination of stable isotope analysis as a means for tracing carbon pathways in stream ecosystems. Canadian Journal of Fisheries and Aquatic Sciences 52:651-656.

Hamilton, S. K., S. J. Sippel, and S. E. BunN. 2005. Separation of algae from detritus for stable isotope or ecological stoichiometry studies using density fractionation in colloidal silica. Limnology and Oceanography: Methods 3:149-157.

Herbst, M., C. Eschenbach, And L. Kappen. 1999. Water use in neighbouring stands of beech (Fagus sylvatica L.) and black alder (Alnus glutinosa (L.) Gaertn.). Annals of Forest Science 56:107-120.

Hobson, K. A., L. Atwell, and L. I. WassenaAr. 1999. Influence of drinking water and diet on the stablehydrogen isotope ratios of animal tissues. Proceedings of the National Academy of Sciences of the United States of America 96:8003-8006.

Jardine, T. D., E. Chernoff, And R. A. Curry. 2008a. Maternal transfer of carbon and nitrogen to progeny of sea-run and resident brook trout (Salvelinus fontinalis). Canadian Journal of Fisheries and Aquatic Sciences 65:2201-2210.

Jardine, T. D., And R. A. CunJAK. 2005. Analytical error in stable isotope ecology. Oecologia (Berlin) 144:528-533.

Jardine, T. D., R. A. Curry, K. S. Heard, and R. A. Cunjak. 2005. High fidelity: isotopic relationship between stream invertebrates and their stomach contents. Journal of the North American Benthological Society 24:290-299. 
Jardine, T. D., K. A. Kidd, J. T. Polhemus, and R. A. Cunjak. 2008b. An elemental and stable isotope assessment of water strider feeding ecology and lipid dynamics: synthesis of lab and field studies. Freshwater Biology 53:2192-2205.

Junk, W. J., P. B. Bayley, and R. E. Sparks. 1989. The flood pulse concept in river-floodplain systems. Pages 110-127 in D. P. Dodge (editor). Proceedings of the International Large River Symposium. Canadian Special Publication of Fisheries and Aquatic Sciences 106.

Kendall, C., and T. B. Coplen. 2001. Distribution of oxygen18 and deuterium in river waters across the United States. Hydrological Processes 15:1363-1393.

Lau, D. C. P., K. M. Y. Leung, and D. Dudgeon. 2009. What does stable isotope analysis reveal about trophic relationships and the relative importance of allochthonous and autochthonous resources in tropical streams? A synthetic study from Hong Kong. Freshwater Biology 54:127-141.

Logan, J. M., T. D. Jardine, T. J. Miller, S. E. Bunn, R. A. CunjaK, And M. E. Lutcavage. 2008. Lipid corrections in carbon and nitrogen stable isotope analyses: comparison of chemical extraction and modeling methods. Journal of Animal Ecology 77:838-846.

Meier, S., J. Klungsoeyr, T. E. Andersen, and A. Svardal. 2000. Lipid content of stream macroinvertebrates. Archiv für Hydrobiologie 147:447-463.

Moore, J. W., And B. X. Semmens. 2008. Incorporating uncertainty and prior information into stable isotope mixing models. Ecology Letters 11:470-480.

Pendall, E., D. G. Williams, and S. W. Leavitt. 2005. Comparison of measured and modeled variations in pinon pine leaf water isotopic enrichment across a summer moisture gradient. Oecologia (Berlin) 145: 605-618.

Phillips, D. L., AND J. W. GregG. 2001. Uncertainty in source partitioning using stable isotopes. Oecologia (Berlin) 127:171-179.

Post, D. M. 2002. Using stable isotopes to estimate trophic position: models, methods, and assumptions. Ecology 83:703-718.

Post, D. M., C. A. Layman, D. A. Arrington, G. Takimoto, J. Quatrochi, and C. G. Montaña. 2007. Getting to the fat of the matter: models, methods and assumptions for dealing with lipids in stable isotope analyses. Oecologia (Berlin) 152:179-189.

Rosenfeld, J. S., AND J. C. Roff. 1992. Examination of the carbon base in southern Ontario streams using stable isotopes. Journal of the North American Benthological Society 11:1-10.

Schimmelmann, A., M. D. Lewan, and R. P. Wintsch. 1999. D/ $\mathrm{H}$ isotope ratios of kerogen, bitumen, oil, and water in hydrous pyrolysis of source rocks containing kerogen types I, II, IIS, and III. Geochimica et Cosmochimica Acta 63:3751-3766.

Sessions, A. L., T. W. Burgoyne, A. Schimmelmann, and J. M. HAYES. 1999. Fractionation of hydrogen isotopes in lipid biosynthesis. Organic Geochemistry 30:1193-1200.

Shafroth, P. B., J. R. Cleverly, T. L. Dudley, J. P. Taylor, C. Van Riper, E. P. WeEKs, and J. N. Stuart. 2005. Control of Tamarix in the western United States: implications for water salvage, wildlife use, and riparian restoration. Environmental Management 35:231-246.

Solomon, C. T., J. J. Cole, R. R. Doucett, M. L. Pace, N. D. Preston, L. E. Smith, and B. C. Weidel. 2009. The influence of environmental water on the hydrogen stable isotope ratio in aquatic consumers. Oecologia (Berlin) (in press).

Thompson, R. M., And C. R. Townsend. 2005. Energy availability, spatial heterogeneity and ecosystem size predict food-web structure in streams. Oikos 108: 137-148.

Thorp, J. H., And M. D. Delong. 1994. The riverine productivity model: an heuristic view of carbon sources and organic processing in large river ecosystems. Oikos 70:305-308.

Tuross, N., C. Warinner, K. Kirsanow, And C. Kester. 2008. Organic oxygen and hydrogen isotopes in a porcine controlled dietary study. Rapid Communications in Mass Spectrometry 22:1741-1745.

Vannote, R. L., G. W. Minshall, K. W. Cummins, J. R. Sedell, AND C. E. Cushing. 1980. The River Continuum Concept. Canadian Journal of Fisheries and Aquatic Sciences 37: 130-137.

Walker, C. D., AND J. P. BRUnel. 1990. Examining evapotranspiration in a semi-arid region using stable isotopes of hydrogen and oxygen. Journal of Hydrology 118: $55-75$.

Wallace, J. B., S. L. Eggert, J. L. Meyer, and J. R. Webster. 1997. Multiple trophic levels of a forest stream linked to terrestrial litter inputs. Science 277:102-104.

WassenaAr, L. I., AND K. A. Hobson. 2000. Improved method for determining the stable-hydrogen isotopic composition $(\delta \mathrm{D})$ of complex organic materials of environmental interest. Environmental Science and Technology 34: 2354-2360.

WassenaAr, L. I., and K. A. Hobson. 2003. Comparative equilibration and online technique for determination of non-exchangeable hydrogen of keratins for use in animal migration studies. Isotopes in Environmental and Health Studies 39:211-217.

ZHANG, Z., AND J. P. SACHS. 2007. Hydrogen isotope fractionation in freshwater algae: 1. Variations among lipids and species. Organic Geochemistry 38:582-608.

Received: 10 April 2009

Accepted: 7 August 2009 